\title{
CORRESPONDENCE
}

\section{The DNA disease}

SIR - This is an account of a disease which has recently attained epidemic proportions. In February 1975 at a meeting held at Asilomar Conference Centre in California, many scientists and the world at large first learned of recent developments which came to be known as the recombinant DNA molecule technique, whereby genetic information initially in one organism could be translocated into another where, with reasonable luck, it might prosper and ultimately find expression. This announcement was followed by a wave of anxiety among the knowledgeable. It was confidently forecast that among the new chimaeras which might thus be generated there would be some that were malevolent. New toxic gene products would be let loose in the world and organisms which had, for millennia, lived in friendly symbiosis would be rudely ejected from their econiches by novel and hostile forms.

The assembled scientists at Asilomar therefore agreed to conduct their experiments under severe constraints of biological and physical containment. The intent of these regulations, drafted as "guidelines" by the Recombinant DNA Molecule Program Advisory Committee of the National Institutes of Health, was to minimize the likelihood of any of the foreseeable catastrophes.

It is now quite generally agreed that the anxieties which were initially generated were without much substance. Curiously, however, the one serious damage to our ecosystem which has now been observed to occur as a result of application of the recombinant DNA molecule technique was totally unanticipated in 1975.

The problem has arisen as a result of the discovery that some of the gene products derived from recombinant DNA experiments commanded a high market value. The gene which was enhanced was that for venality and the unanticipated gene product was money sometimes in the form of shares in an entrepreneurial company - sometimes in the form of stock options. This gene product to which many investigators had not previously been exposed might well have been contained had the experiments been conducted under appropriate physical containment such as that in a bank vault. However, the new disease proved to be quite contagious, spreading rapidly even to the administration of the institutions in which these scientists were housed. With great eagerness, everyone wanted a piece of the action.

Among the symptoms of the disease most prominent has been a deterioration in communication, both verbal and written, on the part of those affected. They simply will not tell their friends and neighbours what they are doing or what they intend to do. Both teacher and student have schooled themselves to be close-lipped lest the competitor discover the name of the new product or the means to its production.

Concurrently, a change was noted in the dissertation problems assigned to graduate students. Whereas these formerly always contained an element of new knowledge, now the stress is more towards a new product and preferably a marketable one. The student may not be assured of what would formerly be termed an excellent graduate education, but he is more or less guaranteed a well-paid job at the end of the road. In some instances, if the entrepreneurial company is remote from the campus at which the professor is nominally employed, the academic chair which he is expected to occupy may be vacant much of the time. Science gives way to technology, research to development and publication to patent. Lip service, of course, is still paid to basic research, but clearly the product is the thing. For what is an entrepreneurial company without a product?

The prognosis for this epidemic is, at present, unfavourable. So far no treatment for the disease has been forthcoming; and whereas measures to prevent its further spread can be imagined, no one seems to have the strength or the authority to impose the rigid quarantines that would be necessary. Readers of the Arabian Nights may recall what happened when, inadvertently, the genie was allowed to escape from the bottle. Having allowed the venality gene to escape, we cannot foresee how the matter will ever be put right again.

DeWitT STETten JR Department of Health \& Human Services, National Institutes of Health,

Bethesda, Maryland, USA

\section{Turkish rights}

SIR - As a foreigner who has studied and taught in Turkey for about eight years, I found your version of Dr Ogelman's case lacking rationalism and credibility (Nature 25 February, p.638; 18 March, p.186).

I was a member of the faculty of the Middle East Technical University at Gaziantep during the academic years when the internal political strife and violence on the Turkish campuses and in the streets was at its peak. It is no secret that some of the faculty at our campus, and indeed at every other campus, were openly involved in supporting the extreme right or left. As a matter of fact, during those days it was almost impossible and certainly very dangerous not to take sides, which meant inviting the wrath and enmity of both sides. At our university, where the leftist students and the faculty had the upper hand, anyone trying to be neutral and reasonable was branded as a fascist, which made the foreign faculty members, like myself and other North American and West Europeans, very vulnerable and insecure. My office and classroom were heavily pelted with stones for just beginning a lecture on the date when some leftist student had been jailed or hanged in the past. There were daily incidents of bombing and stabbing inside and outside university campuses and everyone lived in an atmosphere of terror.

Active collusion of a part of the faculty with the criminal elements of both the right and the left frustrated the efforts of the university administration to bring about normalization. The police, who could not enter the university premises without prior authorization from the university, usually waited outside as passive and helpless observers while mobs of unruly students of a majority group kept the other students outside the university grounds.

I am neither familiar with the facts of $\mathrm{Dr}$
Ogelman's case nor is it my intention to defend the policies and/or practices of the Turkish government. It is, however, a known fact that Cukorova University, which was only a couple of hours drive from us, was the scene of repeated violence and had to be shut down frequently. You state that "Dr Ögelman has been prosecuted not because she is a physicist but because of her part in an organization intended to secure rights for women in a society in which these have recently been denied".

I am afraid that the basis of your above statement as well as your advocacy for the cause of freedom for the Turkish scientific community need to be re-examined objectively and impartially. First of all, the rights of the Turkish women are solidly entrenched in the constitution. I have made several inquiries here and no one seems to know what rights the Turkish women have been denied recently and how Dr Ogelman's organization is planning to restore those rights. In this connection, it would have been helpful if you had included the name of that organization also. From my own experience and knowledge as a resident of Turkey for almost eight years, I have no hesitation in saying that the Turkish women enjoy more rights and have far greater opportunities for advancement than the women of North America.

As a scientist living and working in a free society, I appreciate and support your efforts in publicizing the plight of fellow scientists under oppression, but such incidents must be presented along with credible evidence which, in my opinion, has not been done in $\mathrm{Dr}$ Ögelman's case.

M.H. SADAR

Middle East Technical University, Gaziantep, Turkey

SIR - Your article "Turkish illiberality" (Nature $18 \mathrm{March}$, p.186) is a completely erroneous interpretation of the liberality in Turkey today. Being the co-author of the research paper published in the same issue of your journal (p.231), I must protest strongly at your misinterpretation of the situation of people with limited freedom in my country. Above all, the fact that you equate the Turkish martial law authorities with the Polish and Argentinian martial law authorities has driven me to think that your long established, serious and scientifically respected journal is taking advantage of its position by resorting to cheap politics.

As you should know, Turkish women gained their rights in 1923 under the great leader Atatürk. The women's organization mentioned in your article has attempted to give a misleading impression of the Turkish community, which consists of wholly liberated women. Scientists are human too; they can commit wrongs and rights, and can be condemned or set free.

The martial law authorities in Turkey have not limited liberality and democracy, but on the contrary have created an atmosphere of pleasantness and friendship between people who were enemies before the present regime took power. Above all, their existence has eliminated anarchy and its fatal consequences.

Adana, Turkey

SELIM KAPUR 